\title{
New Variety of Sweet Pepper (Capsicum annuum var. Grossum) Obtained at V.R.D.S. Buzău
}

\author{
Elena BARCANU-TUDOR ${ }^{1 *}$, Elena Maria DRĂGHICI², Costel VÎNĂTORU ${ }^{1}$ \\ ${ }^{1}$ Vegetable Research and Development Station Buzău, 23 Mesteacănului Street, 120024, Buzău, \\ Romania \\ ${ }^{2}$ University of Agronomic Sciences and Veterinary Medicine of Bucharest, 59 Marasti Blvd, District 1, \\ Bucharest, Romania \\ *corresponding author: barcanuelena@yahoo.com
}

Bulletin UASVM Horticulture 75(1) / 2018

Print ISSN 1843-5262, Electronic ISSN 1843-536X

DOI:10.15835/buasvmcn-hort: 002917

\begin{abstract}
Obtaining new varieties of sweet peppers has been a major and permanent concern at V.R.D.S. Buzau. Autochthonous assortment in this species is relatively small compared to other species which led to the crop extension of foreign varieties that are commercialized at high prices without the expected results. Researches carried out during the period 1996-2017 aimed to contribute at the enrichment and diversification of autochthonous germplasm collection and also allowed introducing new valuable cultivars according to the market requirements nowadays.
\end{abstract}

Keywords: breeding, genotypes, Ideal

\section{Introduction}

There is a huge kinds of peppers (Solanaceae) grown worldwide with different shapes and colors. The pepper usage is as diverse as the types of Capsicum fruits (Albrecht et al., 2012). Peppers are an important source of nutrients in the human diet (Shetty et al., 2013), and it can be consumed fresh or dried. They promote health benefits such as reducing obesity and diabetes (Vasconcelos, 2016). Moreover, pepper are noted for their antiaging and cognitive enhancing properties. Also, recent studies suggest that a possible dietary means of managing Alzheimer's disease (Ogunruku et al., 2017). Under Romania's pedoclimatic conditions, pepper behaves like an annual plant, being sensitive to extreme environmental conditions and to the attack of pathogens. Currently, the sweet pepper crops hold one of the major areas of cultivated vegetable, but, unfortunately, most of the cultivars belong to foreign origin. In Romania, there is a small number of autochthonous varieties, but most of them with limited yield potential and that is why it has been highlighted the necessity to improve the existing assortment of cultivars.

Aims and objectives. The aim of this study was to achive new variety of sweet pepper suitable for specific pedoclimate conditions of Romania and also to the market requirements nowadays.

\section{Materials and methods}

The experiments were carried out in Vegetable Research and Development Station Buzau (V.R.D.S.) site. The germplasm collection of V.R.D.S. Buzau consists of 214 accessions of Capsicum spp. grouped by degree of genetic stability: stable, advanced and segregating. After evaluating the germplasm collection, a special attention has been granted to Capsicum annuum var. grossum. Researches have been completed so far with the achievement through repeated individual selection of a new genetically stabilized variety that exhibits features with limited variability that 


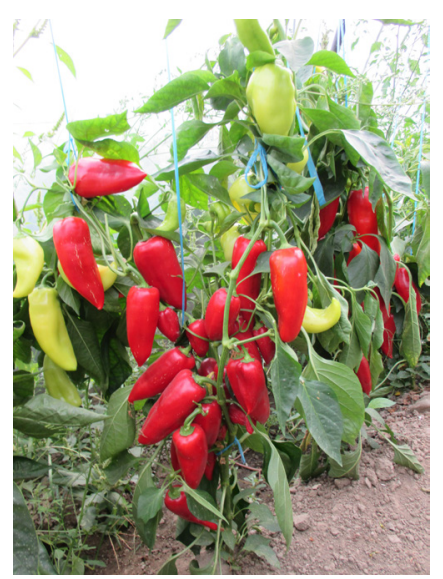

Figure 1. Plant detail

Table 1. Main characteristics of plant

\begin{tabular}{cccccc}
\hline Character/years & 2013 & 2014 & 2015 & 2016 & Average \\
\hline Average plant height $(\mathrm{cm})$ & 85,3 & 92,5 & 98,8 & 112,1 & 97,17 \\
\hline Average bush diameter $(\mathrm{cm})$ & 70,2 & 73,1 & 75,7 & 71,9 & 72,72 \\
\hline Average number of main shoot/sprout & 3,1 & 3,2 & 3,4 & 4,7 & 3,6 \\
\hline Average number of second shoot/sprout & 6,2 & 7,5 & 8,7 & 8,3 & 7,675 \\
\hline
\end{tabular}

Table 2. Main fruit characteristics

\begin{tabular}{cccccc}
\hline Character/years & 2013 & 2014 & 2015 & 2016 & Average \\
\hline Average numbers of fruits /plant & 21,4 & 22,2 & 21,4 & 24,1 & 22,27 \\
\hline Average fruit mass (g) & 95,2 & 126,4 & 129,7 & 131,4 & 120,67 \\
\hline Average fruit wall thickness (cm) & 0,6 & 0,6 & 0,7 & 0,7 & 0,65 \\
\hline Average pulp weight (g) & 105,2 & 108,8 & 111,1 & 113,7 & 109,7 \\
\hline Average yield/plant (kg) & 2,037 & 2,806 & 2,775 & 3,166 & 2,70 \\
\hline
\end{tabular}

accomplish the specific targets for breeding. The breeding material used in obtaining this variety was accession no. 3. The statistical analysis had been made and mean and standard error of mean had been calculated. Due to results obtained, there have been made appreciations on the variability of the studied characters and selection works have been carried out.

\section{Results and discussion}

After the breeding work was finalized, the variety had been cultivated and studied in the experimental field between 2013 - 2016 and it had been subjected to conservative selection work. Over a 4-year period (2013-2016), peppers were grown in greenhouse following current recommendations for sweet pepper production. Care was taken to ensure similar agrotehnical conditions in each year. In table 1 are presented the main characteristic of plants.
Sweet pepper variety has a medium-strong growth habit, with woody stem that grows brightly colored fruits, as seen in Figure 1. The fruits can be harvested in both stages: green (unripe) when fruit has reached length of $12,2 \mathrm{~cm}$ and red (ripe) when fruits records an average of $15,3 \mathrm{~cm}$. At physiological maturity, the taste and aroma are more pronounced, giving the variety a better feature. The fruit has a triangular shape, with two lobes and a red carmine color at physiological maturity. In Table 2 are presented three of the main components of plant productivity: the average weight of fruit, the number of fruits on plant and fruits yield on plant. Also, there are fruits characteristics like pulp weight and thickness wall.

As a result of the selection process, the variability limits characters decreased significantly from year to year and an increase in the yield on the plant was observed, reaching a significant increase up to $1.129 \mathrm{~kg} /$ plant. In addition to the positive 
effect of the selection process the pedoclimate conditions of 2016 were favorable which has also led to an increase of the yield.

\section{Conclusion}

The researches ended with the creation of a new sweet pepper variety that passed the final test at ISTIS and is being patented as 'Ideal.' It is particularly characterized as a medium-sized plant with a medium-strong growth habit, suited for greenhouses, with attractive fruits suitable for both green and red stage. Fruits have a firm fruit wall and a leathery peel, when fruits ripes tend to be sweeter than in immature green stage. Promotional seeds and seedlings were offered in the main vegetable centers in Romania and the results are encouraging. This new variety contributes to the enrichment of the Romanian genetic patrimony, especially for the yield in greenhouses.

\section{References}

1. Albrecht E, Zhang D, Saftner RA, Stommel RJ (2012). Genetic diversity and population structure of Capsicum baccatum genetic resources. Genetic Resources and Crop Evolution, 59(2): 517-538.

2. Ogunruku 00, Oboh G, Passamonti S, Tramer F, Boligon AA (2017). Capsicum annuum var. grossum (Bell Pepper) Inhibits $\beta$-Secretase Activity and $\beta$-Amyloid1-40 Aggregation. Journal of medicinal food, 20(2): 124-130.

3. Shetty AA, Magadum S, Managanvi K (2013). Vegetables as sources of antioxidants. Journal of Food \& Nutritional Disorders, 2(1): 1-5.

4. Vasconcelos CS (2016). Recursos genéticos de pimentas (Capsicum,Solanaceae): qualidade de frutos após a colheita e ação dos compostos antioxidantes na prevençãoda síndrome metabólica, Ph.D.Thesis, Universidade Federal de Pelotas - RS, Brazil. 